\title{
Relationships between Plant Biodiversity and Soil Fertility in a Mature Tropical Forest, Costa Rica
}

\author{
Martin B. Nadeau ${ }^{1,2}$ and Thomas P. Sullivan ${ }^{1}$ \\ ${ }^{1}$ Department of Forest and Conservation Sciences, Faculty of Forestry, The University of British Columbia, 2424 Main Mall, \\ Vancouver, BC, Canada V6T $1 Z 4$ \\ ${ }^{2}$ Escuela de Biología, Universidad de Costa Rica, 11501-2060 San José, Costa Rica
}

Correspondence should be addressed to Martin B. Nadeau; martin.beaudoin.nadeau@gmail.com

Received 1 December 2014; Revised 3 February 2015; Accepted 4 February 2015

Academic Editor: Piermaria Corona

Copyright ( $) 2015$ M. B. Nadeau and T. P. Sullivan. This is an open access article distributed under the Creative Commons Attribution License, which permits unrestricted use, distribution, and reproduction in any medium, provided the original work is properly cited.

\begin{abstract}
We aimed to study relationships between plant biodiversity and soil chemical fertility in a mature tropical forest of Costa Rica. Soil samples were collected in nine sampling plots $(5 \mathrm{~m}$ by $25 \mathrm{~m}$ ) in order to identify $\mathrm{P}, \mathrm{K}, \mathrm{Ca}, \mathrm{Mg}, \mathrm{Fe}, \mathrm{Zn}, \mathrm{Mn}, \mathrm{Cu}$, and $\mathrm{Al}$ and total $\mathrm{N}$ contents, soil fertility index, CEC, $\mathrm{pH}$, and $\mathrm{C} / \mathrm{N}$ ratio. Furthermore, species richness, Shannon-Wiener and Simpson's species diversities, structural richness, and structural diversity were calculated for each plot. Simple linear regression analyses were conducted. Tree species richness was inversely related to concentration levels of $\mathrm{K}$, Ca, and P, CEC, and soil fertility index. Therefore, higher tree species richness tended to be found on sites with lower soil fertility, which is the complete opposite of temperate forests. As a result, tropical and temperate forest ecology should be considered separately. Shannon-Wiener tree species diversity was positively correlated to $\mathrm{C} / \mathrm{N}$ ratio. Herb structural richness was positively correlated with soil fertility index and $\mathrm{P}$ concentration. Therefore, herb structural richness may be a good indicator of soil fertility. This study gives important insights on ecological relationships between plant biodiversity and soil chemical fertility in a primary tropical forest.
\end{abstract}

\section{Introduction}

Tropical forest ecosystems are known for having the highest plant biodiversity on the planet. Amazonian tropical forests can support life for up to and even more than 280 tree species per hectare [1]. In Ecuador, 1,104 tree species were found living in an area of 25 ha [1]. This high plant biodiversity is essential for the survival of several living organisms that thrive in tropical ecosystems. It is thought that high plant biodiversity in tropical forest stands is mainly caused by factors such as high stable temperature (low seasonality), high humidity (high precipitation), and high solar radiation all year round which favour the growth of a large number of species [2]. Although the main causal factors of plant biodiversity are related to climate and topography, it is important to understand what is happening at the microhabitat level. Does soil fertility have any effects on plant biodiversity in a mature tropical forest? Conversely, does plant biodiversity have any effects on soil fertility in tropical ecosystems? Is there a relationship between the two?

Waide et al. [3] reviewed literature on the relationship between plant productivity and species richness in desert, boreal forest, tropical forest, and wetland ecosystems. They concluded that trends are variable and the relationship between plant biodiversity and productivity may vary according to different habitats and can also be influenced by other abiotic and biotic factors [3]. Pärtel et al. [4], on the other hand, investigated plant diversity-productivity relationship patterns from 163 case studies all around the world. 80\% of the relationship variation was explained by latitude [4]. The unimodal relationship in which productivity is low at low and very high diversity and is high at medium diversity seemed to dominate the temperate regions [4]. In a more specific study, Janssens et al. [5] looked at the relationship between plant biodiversity and different soil chemical factors in numerous sites located in temperate grassland ecosystems. They found 


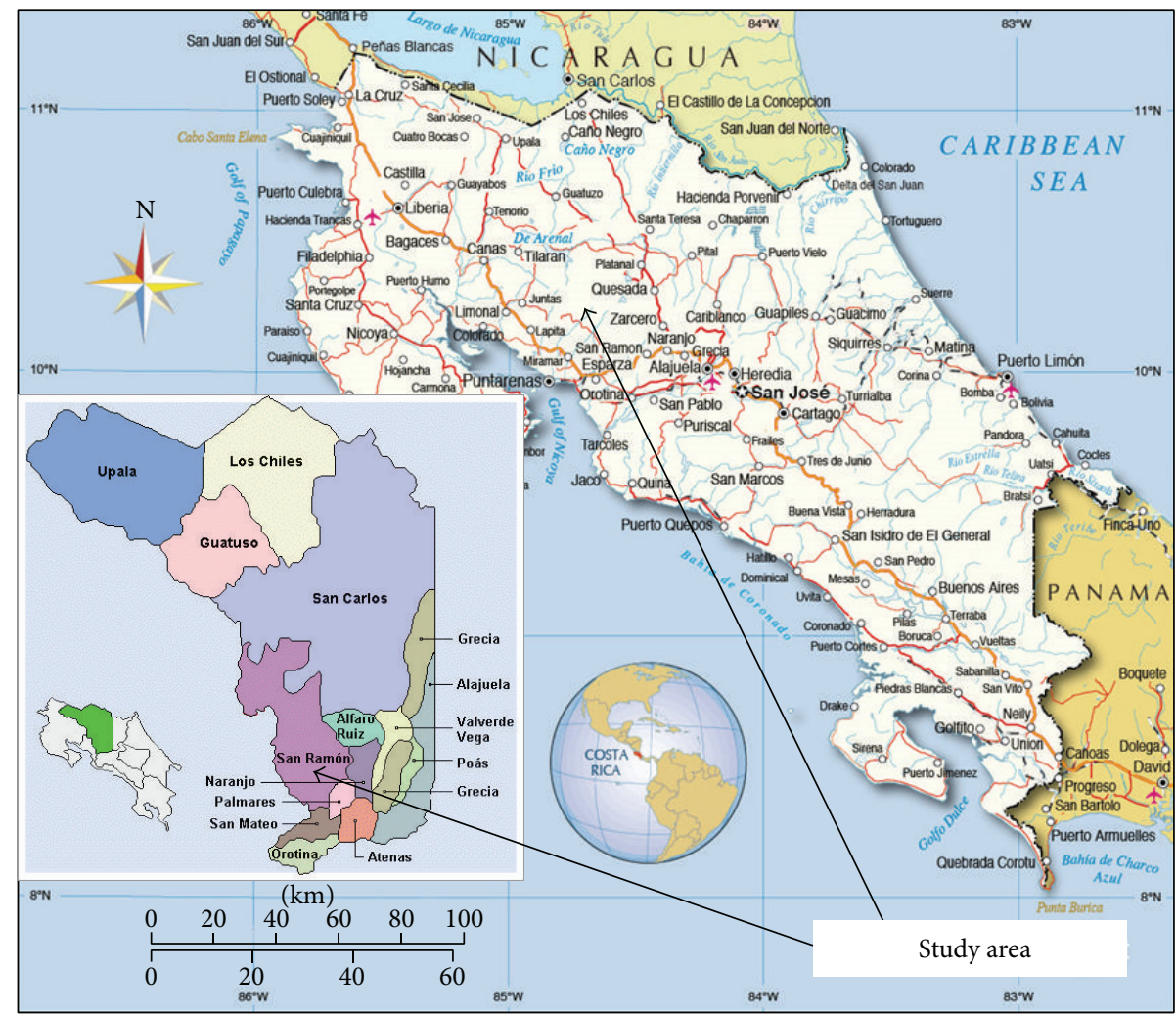

Figure 1: Map with location of the study area “Reserva Biológica Alberto Manuel Brenes de San Ramón," Costa Rica (coordinates: $10^{\circ} 16^{\prime} 00.94^{\prime \prime} \mathrm{N}$ and $84^{\circ} 36^{\prime} 36.02^{\prime \prime} \mathrm{W}$ ).

a positive relationship between plant biodiversity (richness and diversity) and the concentration of extractable $\mathrm{P}$ and $\mathrm{K}$ in soil [5]. No relationship was found between plant biodiversity and other factors such as total $\mathrm{N}$ and Ca concentrations, $\mathrm{pH}$, and organic matter content [5]. In temperate regions, Tilman et al. [6] investigated the effects of species richness and diversity on ecosystem productivity. They found that nitrogen was more available to plant roots in plots with higher species richness and diversity due to the reduction of $\mathrm{N}$ leaching loss in soil, thereby increasing ecosystem productivity at the same time [6]. Using a different approach, Holl [7] compared plant biodiversity and soil chemical fertility in an abandoned pasture versus a near primary tropical forest of southern Costa Rica. He found that the levels of most soil nutrients ( $\mathrm{N}, \mathrm{Ca}, \mathrm{Mg}$, and especially $\mathrm{P}$ ) were usually lower in the pasture compared to the forest containing higher plant biodiversity [7]. Recently, Dybzinski et al. [8] investigated the effects of plant species diversity on productivity in a grassland ecosystem of Minnesota in the United States. They found that soil from the higher plant species diversity plots was producing more biomass than soil from lower diversity plots and this phenomenon was caused by greater soil $\mathrm{N}$ availability, inputs, and retention [8]. Then, Nirmal Kumar et al. [9] studied the relationship between tree species biodiversity (Shannon-Wiener and Simpson's diversities and species richness) and soil nutrient concentration in three different sites in a dry deciduous forest of western India. They found a strong positive correlation between tree species richness and the concentrations of $\mathrm{N}, \mathrm{P}$, and C [9].
Much research has been done on the relationships of plant biodiversity with productivity and soil fertility in grassland ecosystems, temperate forest stands, and agroecosystems. On the other hand, there is a lack of research and data available about this correlation in tropical forest ecosystems. In this study, we aimed to investigate the relationship between plant biodiversity and soil chemical fertility in a mature tropical forest of Costa Rica. We tested the hypothesis that there are some relationships between different plant biodiversity measurements (species richness, Shannon-Wiener and Simpson's species diversity, and structural richness and diversity) and soil chemical fertility factors (concentration of exchangeable $\mathrm{K}, \mathrm{Ca}$, and $\mathrm{Mg}$; Olsen $\mathrm{P}, \mathrm{Fe}, \mathrm{Cu}, \mathrm{Zn}, \mathrm{Mn}$, and $\mathrm{Al}$; and $\mathrm{CEC}$, $\mathrm{pH}, \mathrm{C} / \mathrm{N}$ ratio, soil fertility index, and total $\mathrm{N}$ ). This is the first study that has looked at both plant species and structural diversities in relation to soil chemical fertility in a tropical forest.

\section{Study Area and Methods}

2.1. Study Area. Data were collected in the "Reserva Biológica Alberto Manuel Brenes," district of San Ramón, in the province of Alajuela, Costa Rica (Figure 1). It is a biological reserve of 7,800 ha consisting of mature tropical forests with elevation varying between $800 \mathrm{~m}$ and 1,500 $\mathrm{m}$ above sea level. The precipitation varies between $3,500 \mathrm{~mm}$ and $6,000 \mathrm{~mm}$ per year and the temperature ranges from $17^{\circ} \mathrm{C}$ to $25^{\circ} \mathrm{C}$ with an annual average of $21^{\circ} \mathrm{C}$. This kind of climate and variable 


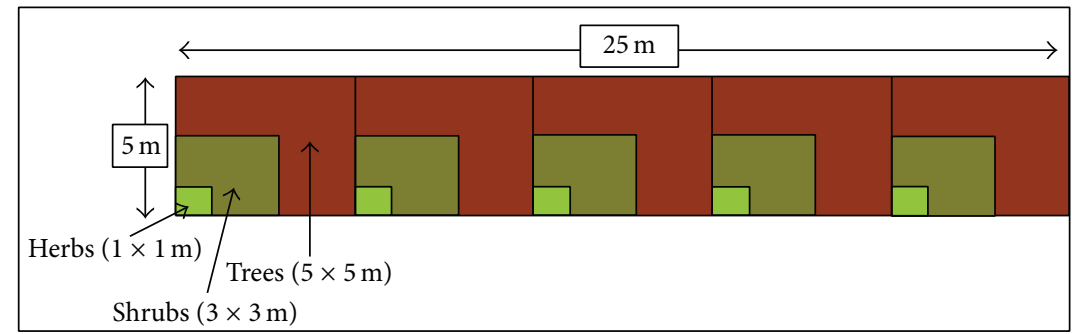

FIGURE 2: Sampling plot in which abundance and height class of herbs, shrubs, and trees species were measured.

topography results in the presence of three types of forest called Premontane Moist Forest, Premontane Wet Forest, and Premontane Rain Forest. The forest types were identified using the life zone system created by Holdridge [10].

This reserve is located in an area known for its soils classified mainly as Inceptisols which tend to be moderately acid and contain low concentration levels of $\mathrm{Ca}, \mathrm{Mg}, \mathrm{K}$, and $\mathrm{Zn}$. The relief tends to be abrupt. Furthermore, the reserve shelters high plant species richness in which 1,012 species of angiosperms have been identified in the past [11].

\subsection{Inventory of Plant Composition and Abundance and Biod-} iversity Calculations. Three sampling plots of $5 \mathrm{~m}$ by $25 \mathrm{~m}$ area were randomly selected in each of the three life zones [12]. Life zones are defined by the variation of temperature and precipitation in a given area which leads to the formation of different vegetation communities [10]. Life zones were identified based on elevation and presence of mosses and ferns on tree trunks. Premontane Moist Forest was located in elevations between $700 \mathrm{~m}$ and $1,000 \mathrm{~m}$ and neither moss nor fern was present on tree trunks. Premontane Wet Forest was found in elevations between $1,000 \mathrm{~m}$ and $1,250 \mathrm{~m}$ and trees had low to moderate abundance of mosses and ferns on their bark. Premontane Rain Forest was located in elevations between $1,250 \mathrm{~m}$ and $1,500 \mathrm{~m}$ and had high abundance of mosses and ferns on tree trunks. Sampling was done by randomly selecting, on a map, three sampling plots at least $100 \mathrm{~m}$ apart (located close but at least $25 \mathrm{~m}$ from a trail in order to avoid forest edge effect) in each of the three life zones. There were nine sampling plots analysed in this study. Table 1 shows the corresponding elevation and life zone for each sampling plot. Each plot was divided into five units of $5 \mathrm{~m}$ by $5 \mathrm{~m}$ and the abundance and height class of the different tree species were measured in each of these units [12]. The abundance and height class of the different shrub species were measured from a $3 \mathrm{~m}$ by $3 \mathrm{~m}$ area within each $5 \mathrm{~m}$ by $5 \mathrm{~m}$ unit [12]. Furthermore, the abundance and height class of the different herb species were measured from a $1 \mathrm{~m}$ by $1 \mathrm{~m}$ area within each $3 \mathrm{~m}$ by $3 \mathrm{~m}$ sampling unit [12]. Figure 2 shows how the sampling plots were laid out. The identification of plant species was done using plant identification guides and our knowledge of Costa Rica flora. When it was not possible to identify species in the field, a sample was collected and brought to Carlos Morales, a specialist in Botany at the University of Costa Rica. Epiphytes, vines, and lianas were not included in this study. Table 2 shows the number of species of
TABLE 1: Life zone, elevation, and graphic dot for each sampling plot.

\begin{tabular}{lccc}
\hline Life zone & Elevation $(\mathrm{m})$ & $\begin{array}{c}\text { Sampling plot } \\
\#\end{array}$ & $\begin{array}{c}\text { Graphic dot } \\
\text { form }\end{array}$ \\
\hline Premontane & 822 & 7 & $\square$ \\
Moist Forest & 877 & 8 & $\diamond$ \\
& 943 & 1 & $\triangle$ \\
\hline Premontane & 1,036 & 2 & $\mathrm{X}$ \\
Wet Forest & 1,098 & 9 & $X$ \\
& 1,140 & 4 & - \\
Premontane & 1,309 & 5 & - \\
Rain Forest & 1,393 & 3 & $\bigcirc$ \\
& 1,415 & 6 & + \\
\hline
\end{tabular}

herbs, shrubs, and trees for each plant family encountered in the field.

In each sampling plot, the abundance was measured by visually estimating the percentage of ground that was covered by the crown of a plant species. The area covered $\left(\mathrm{m}^{2}\right)$ by a plant species per hectare was calculated by multiplying the percentage of ground cover, the area of the plot, and the number of plots that fits in one hectare. The height class was measured using a stick which indicates six different height classes $(0-10 \mathrm{~cm}, 11-30 \mathrm{~cm}, 0.3-1 \mathrm{~m}, 1-3 \mathrm{~m}$, and 3-10 $\mathrm{m}$, $\geq 10 \mathrm{~m}$ ). Once the area covered and the height class of plant species had been measured, the mean crown volume index for each sampling plot was calculated by multiplying the area covered by the height and then averaging the crown volume index of the five subplots. This mean crown volume index represents space occupied by each species in a specific sampling plot per 0.01 ha.

Total crown volume index $\left(\mathrm{m}^{3} / 0.01 \mathrm{ha}\right)$ of all species together (herbs, shrubs, and trees separately) was calculated for each sampling plot by adding the mean crown volume index of plant species together. Additionally, overstory (height $\geq 3 \mathrm{~m}$ ) and understory (height $<3 \mathrm{~m}$ ) vegetation crown volume index was calculated. Plant biodiversity was determined by calculating species richness, Shannon-Wiener species diversity, Simpson's species diversity, structural richness, and structural diversity (S-W). These biodiversity indices were chosen because they were the most appropriate for the sampling techniques we used in this study [13]. Species richness is the number of plant species in a given area. Species richness was calculated by counting the number of species 
TABLE 2: Number of species of herbs, shrubs, and trees identified for each family encountered in the field.

\begin{tabular}{|c|c|c|c|}
\hline \multirow{2}{*}{ Family } & \multicolumn{3}{|c|}{ Number of different species } \\
\hline & Herbs & Shrubs & Trees \\
\hline Acanthaceae & & & 3 \\
\hline Anacardiaceae & & & 5 \\
\hline Annonaceae & & & 2 \\
\hline Apocynaceae & & & 1 \\
\hline Araceae & 9 & & \\
\hline Araliaceae & & & 1 \\
\hline Arecaceae & & 8 & 5 \\
\hline Begoniaceae & 2 & & \\
\hline Bignoniaceae & & & 4 \\
\hline Blechnaceae & 2 & & \\
\hline Bombacaceae & & & 3 \\
\hline Boraginaceae & & & 2 \\
\hline Burseraceae & & 1 & 3 \\
\hline Capparidaceae & & & 2 \\
\hline Cecropiaceae & & & 1 \\
\hline Celastraceae & & 1 & \\
\hline Chloranthaceae & & 2 & 1 \\
\hline Clusiaceae & & 1 & 2 \\
\hline Costaceae & & 1 & \\
\hline Cunoniaceae & & 1 & 1 \\
\hline Cyatheaceae & & 2 & \\
\hline Cyclanthaceae & 3 & & \\
\hline Dryopteridaceae & 1 & & \\
\hline Elaeocarpaceae & & & 1 \\
\hline Euphorbiaceae & & & 12 \\
\hline Fabaceae & & & 19 \\
\hline Fagaceae & & & 1 \\
\hline Flacourtiaceae & & 1 & 4 \\
\hline Gesneriaceae & 3 & 2 & \\
\hline Grossulariaceae & & & 1 \\
\hline Heliconiaceae & 6 & & \\
\hline Hymenophyllaceae & 1 & & \\
\hline Icacinaceae & & & 2 \\
\hline Lacistemataceae & & & 2 \\
\hline Lamiaceae & & & 1 \\
\hline Lauraceae & & & 12 \\
\hline Lecythidaceae & & & 1 \\
\hline Lomariopsidaceae & 1 & & \\
\hline Malpighiaceae & & 1 & 1 \\
\hline Malvaceae & & 1 & 7 \\
\hline Maranthaceae & 1 & & \\
\hline Melastomataceae & & 9 & 11 \\
\hline Meliaceae & & & 3 \\
\hline Monimiaceae & & & 1 \\
\hline Moraceae & & & 5 \\
\hline Myristicaceae & & & 2 \\
\hline
\end{tabular}

TABLE 2: Continued.

\begin{tabular}{|c|c|c|c|}
\hline \multirow{2}{*}{ Family } & \multicolumn{3}{|c|}{ Number of different species } \\
\hline & Herbs & Shrubs & Trees \\
\hline Myrsinaceae & & 1 & 9 \\
\hline Myrtaceae & & 1 & 12 \\
\hline Nyctaginaceae & & 1 & 2 \\
\hline Ochnaceae & & & 1 \\
\hline Papaveraceae & & 1 & \\
\hline Piperaceae & & 8 & \\
\hline Polygonaceae & & & 1 \\
\hline Polypodiaceae & 2 & & \\
\hline Pteridaceae & 2 & & \\
\hline Ranunculaceae & 1 & & \\
\hline Rosaceae & & 2 & 2 \\
\hline Rubiaceae & & 23 & 9 \\
\hline Rutaceae & & 1 & 4 \\
\hline Sabiaceae & & & 1 \\
\hline Sapindaceae & & 1 & 9 \\
\hline Sapotaceae & & 1 & 3 \\
\hline Selaginaceae & 2 & & \\
\hline Simaroubaceae & & & 1 \\
\hline Solanaceae & & & 1 \\
\hline Staphyleaceae & & & 1 \\
\hline Turneraceae & & 1 & \\
\hline Urticaceae & & 2 & 1 \\
\hline Vochysiaceae & & & 1 \\
\hline Woodsiaceae & 1 & & \\
\hline
\end{tabular}

that was recorded in each sampling plot. Shannon-Wiener species diversity is a measure of evenness and is affected by both the number of species and evenness of the community [14]. Higher evenness in the abundance of species leads to higher diversity in a community [14]. Shannon-Wiener species diversity was calculated by first calculating the proportion that each plant species had in the community (crown volume index of a species/total volume of all species), then multiplying the proportion of each species by $\log _{2}$, and finally adding the results from the previous calculation together and multiplying it by “- 1 ” (equation: $H^{\prime}=-\sum_{i=1}^{R} p_{i} \log p_{i}, p_{i}=$ proportion). Simpson's species diversity is a measurement of the probability that two individuals randomly selected from a sample will belong to different species and is directly affected by the abundance of species in a community [14]. Higher values mean higher diversity. Simpson's species diversity was calculated by subtracting the sum of the square of proportion from "1" (equation: $\lambda=\sum_{i=1}^{R} p_{i}^{2}, p_{i}=$ proportion). Structural richness is the number of plant height classes in a stand [15]. Structural richness was calculated by counting the number of height classes recorded for each unit and averaging it for each sampling plot. Structural diversity (S-W) refers to the number of layers (microhabitats) in a stand [15]. Structural diversity (S-W) was calculated by first calculating the proportion that each height class had in the community (crown volume index of plants located in a height class/total volume of plants in 
TABLE 3: ANOVA results $(\alpha=0.05)$ and correlation coefficient $(r)$ of the different regressions with $P$ value $\leq 0.10$.

\begin{tabular}{|c|c|c|c|c|c|c|c|c|c|c|c|}
\hline \multirow{2}{*}{$\begin{array}{l}\text { Statistical } \\
\text { parameters }\end{array}$} & \multicolumn{11}{|c|}{ Regressions of the different relationships that were significant ( $P$ value $\leq 0.05$ in bold) or close to be significant $(P$ value $\leq 0.10)$} \\
\hline & $\mathrm{K} * \mathrm{TSR}$ & $\mathrm{K} * \mathrm{HStR}$ & $\mathrm{Ca} * \mathrm{TSR}$ & $\mathrm{Mg} * \mathrm{TSR}$ & $\mathrm{P} * \mathrm{TSR}$ & $\mathrm{P} * \mathrm{HStR}$ & $\mathrm{P} * \mathrm{HStD}$ & $\mathrm{Fe} * \mathrm{TStR}$ & $\mathrm{Fe} * \mathrm{HStD}$ & $\mathrm{Zn} * \mathrm{SStD}$ & $\mathrm{Al} * \mathrm{TWSD}$ \\
\hline$P$ value & 0.04 & 0.08 & 0.05 & 0.054 & 0.047 & 0.01 & 0.09 & 0.06 & 0.06 & 0.08 & 0.07 \\
\hline$r$ & -0.69 & 0.61 & -0.67 & -0.66 & -0.67 & 0.78 & 0.59 & 0.65 & 0.65 & -0.61 & -0.64 \\
\hline Statistical & \multicolumn{11}{|c|}{ Regressions of the different relationships that were significant ( $P$ value $\leq 0.05$ in bold) or close to be significant ( $P$ value $\leq 0.10)$} \\
\hline parameters & $\mathrm{Mn} * \mathrm{HStR}$ & $\mathrm{Mn} * \mathrm{HStD}$ & $\mathrm{CEC} * \mathrm{TSR}$ & $\mathrm{C} / \mathrm{N} * \mathrm{TWSD}$ & $\mathrm{C} / \mathrm{N} * \mathrm{HStR}$ & $\mathrm{C} / \mathrm{N} * \mathrm{SStR}$ & $\mathrm{N} * \mathrm{TWSD}$ & $\mathrm{SFI} * \mathrm{TSR}$ & $\mathrm{SFI} * \mathrm{HStR}$ & $\mathrm{pH} * \mathrm{TStR}$ & \\
\hline$P$ value & 0.07 & 0.04 & 0.03 & 0.01 & 0.09 & 0.10 & 0.07 & 0.01 & 0.04 & 0.06 & \\
\hline$r$ & 0.63 & 0.69 & -0.72 & 0.78 & -0.60 & -0.59 & -0.63 & -0.78 & 0.68 & 0.65 & \\
\hline
\end{tabular}

TSR: tree species richness; HStR: herb structural richness; HStD: herb structural diversity; TStR: tree structural richness; HStD: herb structural diversity; SStD: shrub structural diversity; CEC: cation exchange capacity; C/N: C/N ratio; TWSD: tree Shannon-Wiener species diversity; SStR: shrub structural richness; TStR: tree structural richness; N: total nitrogen in organic matter; SFI: soil fertility index.

all height classes), then multiplying the proportion of each height class by $\log _{2}$, and finally adding the results from the previous calculation together and multiplying it by " -1 " (equation: $H^{\prime}=-\sum_{i=1}^{R} p_{i} \log p_{i}, p_{i}=$ proportion). Diversity is higher when species richness, structural richness, and structural diversity are high.

2.3. Collection of Soil Samples and Analyses. In each sampling plot, three samples of soil and organic matter were collected in order to identify the concentrations of macronutrients $(\mathrm{P}$, $\mathrm{K}, \mathrm{Ca}$, and $\mathrm{Mg}$ ) and micronutrients ( $\mathrm{Fe}, \mathrm{Zn}, \mathrm{Mn}, \mathrm{Cu}$, and $\mathrm{Al}$ ), the cation exchange capacity (CEC) in soil, and the organic matter total $\mathrm{N}$ and $\mathrm{C} / \mathrm{N}$ ratio (Figure 2). Each soil and organic matter sample collected was around $1,000 \mathrm{~cm}^{3}$ of volume and they were taken from the horizon A and the forest floor, respectively. The three samples of soil and organic matter from each sampling plot were put in plastic bags, mixed together, and then brought to the lab for analysis. The samples were sieved $(2 \mathrm{~mm})$ and oven-dried $\left(50^{\circ} \mathrm{C}\right)$. Dumas combustion method (LECO CNS 2000, Mississauga, ON) was used to analyse total $\mathrm{N}$ and organic $\mathrm{C}(\mathrm{g} / \mathrm{kg})$. A sodium bicarbonate solution was used to determine the concentration levels $(\mathrm{mg} / \mathrm{kg})$ of $\mathrm{P}, \mathrm{Fe}, \mathrm{Cu}, \mathrm{Zn}$, and $\mathrm{Mn}$ through spectrophotometry following Olsen modified method [16]. DPTA extraction method was used to determine the concentration levels of exchangeable $\mathrm{K}, \mathrm{Ca}, \mathrm{Mg}$, and extractable acids $(\mathrm{Al}+\mathrm{H})$ in soil [17]. Exchangeable cations were extracted in DPTA and concentrations $(\mathrm{cmol}+/ \mathrm{kg})$ were determined by ICP-AES [17]. The CEC $(\mathrm{cmol}+/ \mathrm{kg})$ was estimated by adding together concentrations of exchangeable K (ppm/390), Ca (ppm/200), $\mathrm{Mg}(\mathrm{ppm} / 120)$, and extractable acids. The $\mathrm{pH}$ was determined in a saturated paste extract and electrical conductivity in $1: 2$ water solution. Soil fertility index for tropical ecosystems was calculated by adding the percentage values of $\mathrm{P}, \mathrm{K}$, and $\mathrm{Ca}$ contents obtained by dividing the concentration in each sampling plot by the mean concentration of the nine sampling plots [18].

2.4. Statistical Analysis. Simple linear regression analyses were used to identify if there was positive or negative relationships between the different plant biodiversity measurements (species richness, Shannon-Wiener diversity, Simpson's diversity, structural richness, and structural diversity) and soil fertility variables $(\mathrm{K}, \mathrm{Ca}, \mathrm{Mg}, \mathrm{P}, \mathrm{Fe}, \mathrm{Cu}, \mathrm{Zn}, \mathrm{Mn}, \mathrm{Al}, \mathrm{pH}$, $\mathrm{CEC}, \mathrm{C} / \mathrm{N}$ ratio, total $\mathrm{N}$, and soil fertility index). Analysis of variance for regression was used to calculate $P$ values and to see if the regressions were significant [19]. The correlation coefficient was calculated using the following equation: " $r=$ $\sqrt{ }\left(\mathrm{SS}_{\mathrm{Reg}} / \mathrm{SS}_{\mathrm{T}}\right)$ " [19]. In all analyses, the level of significance was set at $P=0.05$. 95\% confidence intervals of the variation between subplots for each plant biodiversity measurement were marked in all figures and used to look at differences between life zones and elevations.

\section{Results}

3.1. Relationships between Soil Chemicals Factors and Plant Biodiversity Measurements. Linear regression analysis indicated that tree species richness was negatively related to $\mathrm{K}$ content in soil (Figure 3(a)). This relationship was found to be significant ( $P=0.04$ and $r=-0.69)$ (Table 3). Therefore, the number of tree species declines as the concentration level of $\mathrm{K}$ increases. On the other hand, there was no relationship between $\mathrm{K}$ content and species richness for either the herb $(P$ $=0.91, r=-0.04)$ or shrub $(P=0.63, r=-0.19)$ communities. No relationship was discovered between K concentration in soil and Shannon-Wiener species diversity of herbs $(P=$ $0.20, r=0.47)$, shrubs $(P=0.47, r=-0.28)$, and trees $(P=$ $0.31, r=-0.38)$. Furthermore, there was no relationship encountered between concentration level of $\mathrm{K}$ and Simpson's species diversity of herbs $(P=0.11, r=0.57)$, shrubs $(P=$ $0.74, r=-0.13)$, and trees $(P=0.81, r=-0.09)$. There was no relationship between herb structural richness and $\mathrm{K}$ content $(P=0.08, r=0.61)$. However, it is important to notice that this relationship was close to be significant (Table 3 ). No relationship was observed between $\mathrm{K}$ concentration and structural richness of shrubs $(P=0.33, r=0.37)$ and trees $(P=$ $0.61, r=0.20)$. Also, structural diversity of herbs $(P=0.27, r$ $=0.41)$, shrubs $(P=0.22, r=0.46)$, and trees $(P=0.61, r=$ -0.20 ) was not correlated to $K$ concentration.

Tree species richness was inversely related to Ca concentration in soil (Figure 3(b)). This relationship was found to be significant $(P=0.05, r=-0.67)$ (Table 3$)$. As a result, tree species richness decreased as soil Ca content increased in the mature tropical forest (Figure 3(b)). Conversely, there was no relationship encountered between soil Ca content and species richness of herbs $(P=0.93, r=-0.04)$ and shrubs $(P=$ $0.40, r=-0.32)$. Ca concentration was not correlated to either Shannon-Wiener species diversity of herbs $(P=0.17, r=$ $0.50)$, shrubs $(P=0.57, r=-0.22)$, and trees $(P=0.98, r=$ 


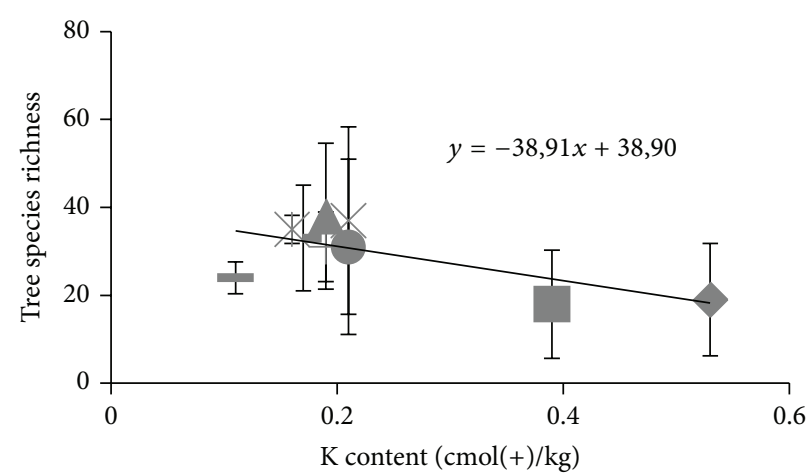

(a)

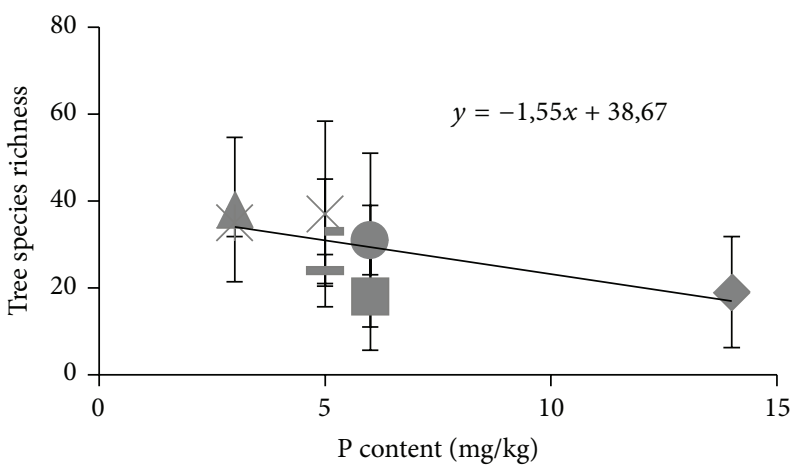

(c)

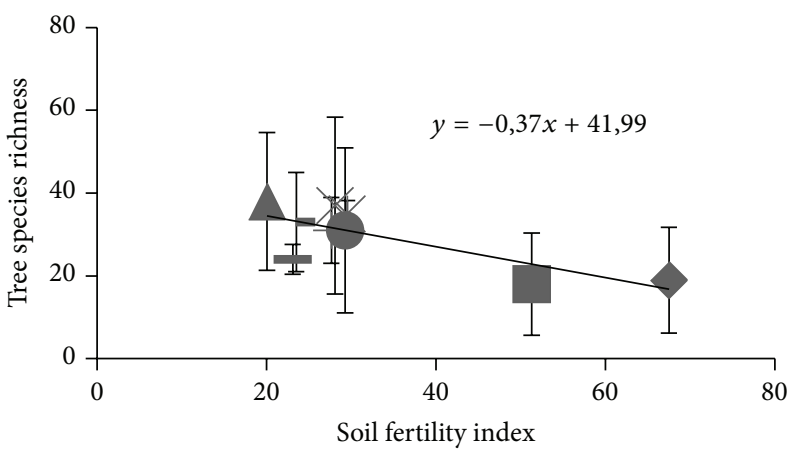

(e)

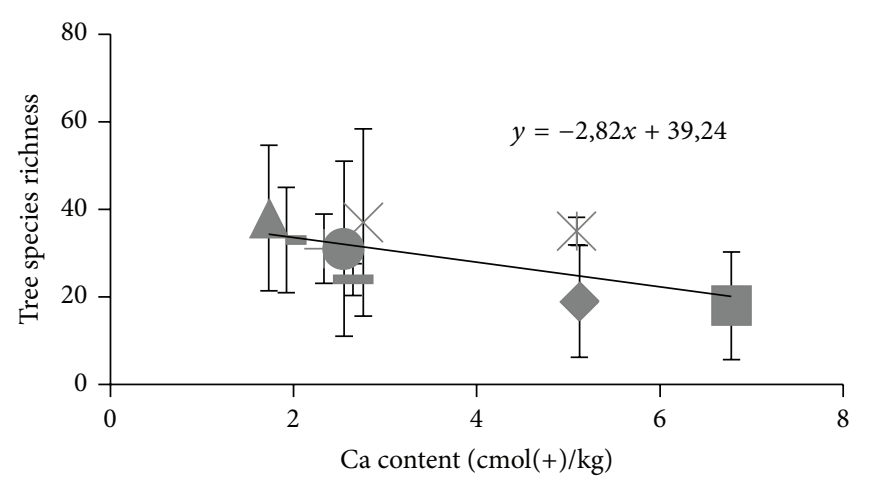

(b)

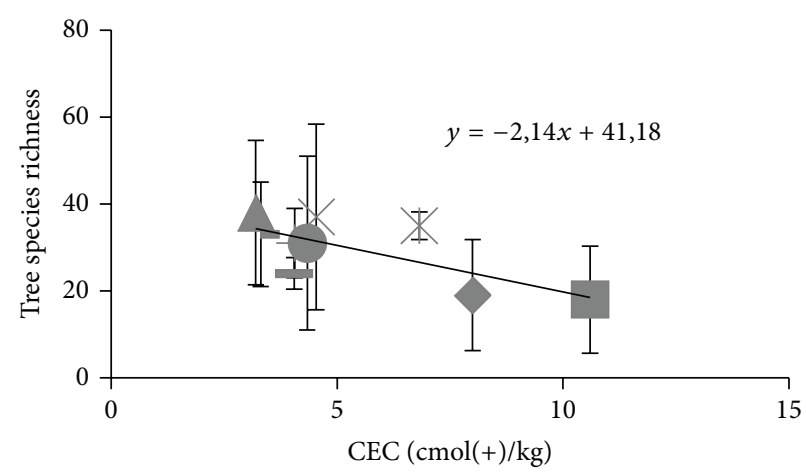

(d)

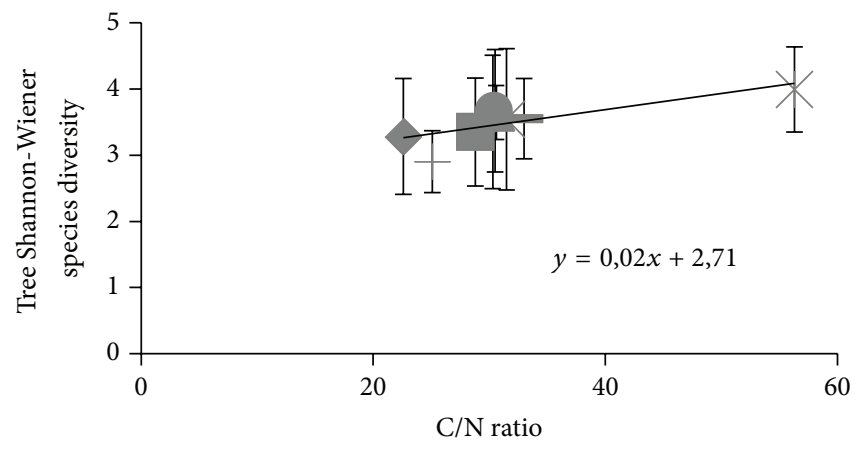

(f)

FIGURE 3: Linear regression relationships between tree species richness and the following soil chemical factors: (a) K content (cmol(+)/kg), (b) Ca content $(\mathrm{cmol}(+) / \mathrm{kg})$, (c) P content $(\mathrm{mg} / \mathrm{kg})$, (d) cation exchange capacity, and (e) soil fertility index and Shannon-Wiener tree species diversity and (f) $\mathrm{C} / \mathrm{N}$ ratio (means $\pm 95 \%$ C.I.).

$0.01)$ or Simpson's species diversity of herbs $(P=0.26, r=$ $0.42)$, shrubs $(P=0.74, r=-0.13)$, and trees $(P=0.57, r=$ 0.22). Additionally, Ca concentration was not related to either structural richness of herbs $(P=0.33, r=0.37)$, shrubs $(P=$ $0.86, r=0.07)$, and trees $(P=0.99, r=0.006)$ or structural diversity of herbs $(P=0.46, r=0.28)$, shrubs $(P=0.94, r=$ $0.03)$, and trees $(P=0.21, r=-0.46)$.

$\mathrm{P}$ concentration in the soil was inversely correlated to tree species richness (Figure 3(c)). The regression was significant $(P=0.047, r=-0.67)$ (Table 3$)$. Therefore, tree species richness decreased as $\mathrm{P}$ concentration increased (Figure $3(\mathrm{c})$ ). On the other hand, there was no relationship between $\mathrm{P}$ concentration and species richness of herbs $(P=0.86, r=$ $-0.07)$ and shrubs $(P=0.97, r=-0.01)$. P concentration was not related to Shannon-Wiener species diversity of herbs $(P=$ $0.31, r=0.38)$, shrubs $(P=0.24, r=-0.44)$, and trees $(P=$ $0.17, r=-0.50)$. Also, it was not related to Simpson's species diversity of herbs $(P=0.24, r=0.43)$, shrubs $(P=$ $0.42, r=-0.31)$, and trees $(P=0.59, r=-0.21)$. Herb structural richness was positively correlated to $\mathrm{P}$ concentration (Figure 4(a)). The regression was significant $(P=$ $0.01, r=0.78$ ) (Table 3 ). Therefore, herb structural richness increased as $\mathrm{P}$ concentration augmented (Figure 4(a)). There was no relationship between $\mathrm{P}$ concentration and structural richness of shrubs $(P=0.16, r=0.51)$ and trees $(P=0.27, r=$ 0.41). $P$ concentration was almost positively related to herb structural diversity with $P=0.09$ and $r=0.59$ (Table 3 ). There was no relationship between $\mathrm{P}$ concentration and structural 


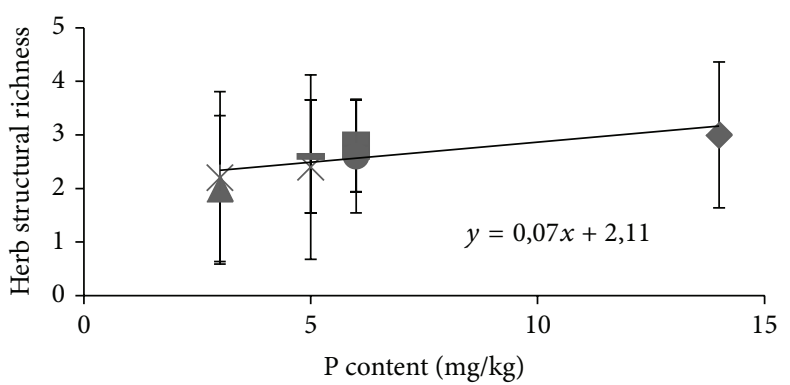

(a)

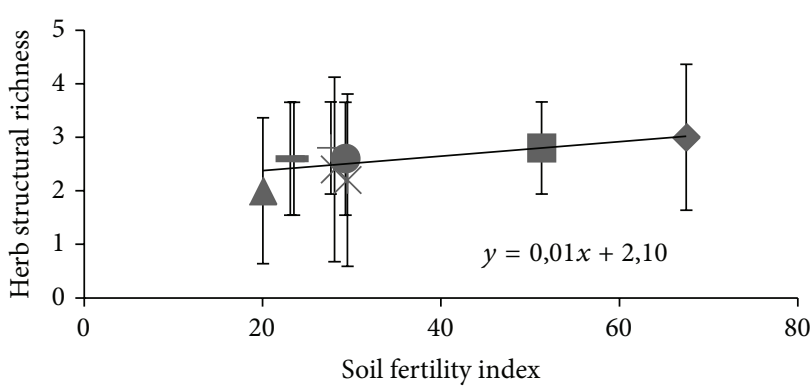

(b)

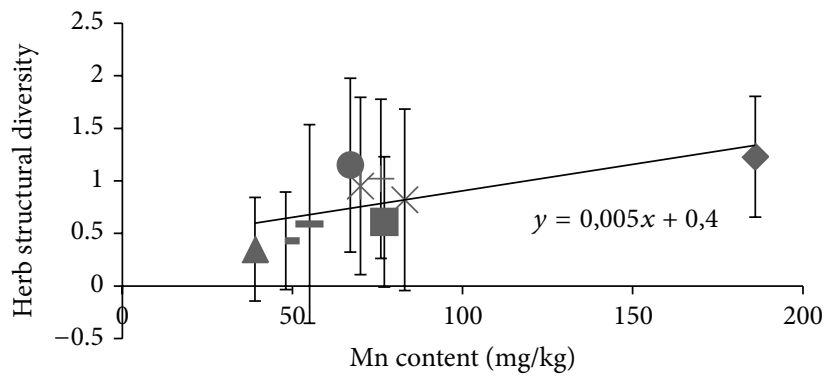

(c)

FIGURE 4: Linear regression relationships between (a) herb structural richness and P content (mg/kg), (b) herb structural richness and soil fertility index, and (c) herb structural diversity and Mn content ( $\mathrm{mg} / \mathrm{kg})$.

diversity of shrubs $(P=0.15, r=0.52)$ and trees $(P=0.67, r=$ $-0.16)$.

There was no relationship between soil Mn content and species richness of herbs $(P=0.94, r=0.03)$, shrubs $(P=$ $0.62, r=-0.19)$, and trees $(P=0.11, r=-0.57)$. Furthermore, Mn concentration was not related to either Shannon-Wiener species diversity of herbs $(P=0.20, r=0.47)$, shrubs $(P$ $=0.26, r=-0.42)$, and trees $(P=0.33, r=-0.37)$ or Simpson's species diversity of herbs $(P=0.32, r=0.38)$, shrubs $(P=0.48, r=-0.27)$, and trees $(P=0.72, r=-0.14)$. Mn concentration was almost positively correlated to herb structural richness, but the regression was not significant $(P=$ $0.067, r=0.63$ ) (Table 3 ). There was no relationship between Mn concentration and structural richness of shrubs $(P=$ $0.52, r=0.25)$ and trees $(P=0.15, r=0.52)$. Herb structural diversity was positively related to $\mathrm{Mn}$ concentration $(P=0.04$, $r=0.69$ ) (Figure 4(c); Table 3). As a result, herb structural richness increased as soil Mn concentration increased (Figure 4(c)). Additionally, there was no relationship between Mn concentration and structural diversity of shrubs $(P=0.32, r$ $=0.38)$ and trees $(P=0.82, r=-0.09)$.

3.2. Relationships between Cation Exchange Capacity and Plant Biodiversity Measurements. Tree species richness was inversely correlated to CEC in soil $(P=0.03, r=-0.72)$ (Figure 3(d); Table 3). Accordingly, the number of tree species in the forest stand increased as CEC decreased in soil (Figure 3(d)). There was no relationship between CEC and species richness of herbs $(P=0.84, r=-0.08)$ and shrubs $(P$ $=0.38, r=-0.33)$. CEC was not related to either ShannonWiener species diversity of herbs $(P=0.17, r=0.50)$, shrubs $(P$ $=0.53, r=-0.24)$, and trees $(P=0.79, r=-0.10)$ or Simpson's species diversity of herbs $(P=0.20, r=0.47)$, shrubs $(P=0.70$, $r=-0.15)$, and trees $(P=0.72, r=0.14)$. Furthermore, it was not correlated to either structural richness of herbs $(P=0.24$, $r=0.44)$, shrubs $(P=0.72, r=0.14)$, and trees $(P=0.89, r$ $=0.06)$ or structural diversity of herbs $(P=0.48, r=0.27)$, shrubs $(P=0.82, r=0.09)$, and trees $(P=0.23, r=-0.45)$.

3.3. Relationships between $\mathrm{C} / \mathrm{N}$ Ratio and Plant Biodiversity Measurements. There was no relationship between $\mathrm{C} / \mathrm{N}$ ratio and species richness of herbs $(P=0.61, r=0.20)$, shrubs $(P=$ $0.83, r=-0.08)$, and trees $(P=0.29, r=0.40)$. Also, $\mathrm{C} / \mathrm{N}$ ratio was not related to either Simpson's species diversity of herbs $(P=0.47, r=-0.28)$, shrubs $(P=0.43, r=0.30)$, and trees $(P=0.11, r=0.57)$ or structural diversity of herbs $(P=$ $0.92, r=-0.04)$, shrubs $(P=0.12, r=-0.55)$, and trees $(P=0.85, r=-0.08)$. On the other hand, tree ShannonWiener species diversity was found to be positively correlated to $\mathrm{C} / \mathrm{N}$ ratio (Figure $3(\mathrm{f})$ ). The regression was significant $(P=$ $0.01, r=0.78$ ) (Table 3 ). Therefore, tree species diversity (S$\mathrm{W})$ tended to increase as the $\mathrm{C} / \mathrm{N}$ ratio augmented in the organic matter (Figure 3(f)). The other two measurements of Shannon-Wiener species diversity (herbs with $P=0.87$ and $r$ $=-0.06$; shrubs with $P=0.39$ and $r=0.33$ ) were not related to $\mathrm{C} / \mathrm{N}$ ratio. Structural richness of herbs and shrubs was almost negatively correlated to $\mathrm{C} / \mathrm{N}$ ratio $(P=0.09, r=-0.60$, and $P=$ $0.10, r=-0.59$, resp.) (Table 3$)$. There was no relationship between tree structural richness and $\mathrm{C} / \mathrm{N}$ ratio $(P=0.67, r$ $=0.17$ ).

3.4. Relationships between Soil Fertility Index and Plant Biodiversity Measurements. There was a negative relationship between tree species richness and soil fertility index $(P=0.01$, 




FIGURE 5: Linear regression relationship between overstory and understory crown volume index $\left(\mathrm{m}^{3} / 0.01 \mathrm{ha}\right)(P=0.91, r=0.04$, means $\pm 95 \%$ C.I.).

$r=-0.78$ ) (Figure 3(e); Table 3). Hence, the number of tree species decreased as soil fertility index increased (Figure 3(e)). There was no relationship between soil fertility index and species richness of herbs $(P=0.88, r=-0.06)$ and shrubs $(P=0.61, r=-0.20)$. Soil fertility index was not related to either Shannon-Wiener species diversity of herbs $(P=0.15$, $r=0.52)$, shrubs $(P=0.34, r=-0.36)$, and trees $(P=0.37, r$ $=-0.34)$ or Simpson's species diversity of herbs $(P=0.13, r$ $=0.55)$, shrubs $(P=0.57, r=-0.22)$, and trees $(P=0.92, r=$ $-0.04)$. Furthermore, soil fertility index was not correlated to either structural diversity of herbs $(P=0.17, r=0.50)$, shrubs $(P=0.29, r=0.40)$, and trees $(P=0.42, r=-0.31)$ or structural richness of shrubs $(P=0.33, r=0.37)$ and trees $(P=0.54, r$ $=0.24)$. Conversely, herb structural richness was positively related to soil fertility index $(P=0.04, r=0.68)$ (Figure $4(\mathrm{~b})$; Table 3 ). Therefore, herb structural richness increased as soil fertility index amplified (Figure 4(b)).

3.5. Other Relationship Results. In this study, soil $\mathrm{Cu}, \mathrm{Mg}$, $\mathrm{Fe}, \mathrm{Zn}$, and $\mathrm{Al}$ contents and $\mathrm{pH}$ and total organic matter $\mathrm{N}$ content were not correlated with any of the biodiversity variables. See Table 4 for more information about $P$ values and correlation coefficients of nonsignificant relationships.

3.6. Differences in Biodiversity between Life Zones and Elevations. Using the significant regression relationships and their corresponding biodiversity 95\% confidence intervals, we found that the relationships were affected by neither elevation nor life zones (Figures 3 and 4). There were no significant differences in tree species richness, tree ShannonWiener species diversity, herb structural richness, and herb structural diversity among life zones and different elevation levels (Figures 3 and 4).

3.7. Overstory versus Understory Vegetation Crown Volume Index. In this study, the understory vegetation crown volume index was neither affected by nor correlated to the overstory tree crown volume index $(P=0.91, r=0.04)$ (Figure 5).

\section{Discussion}

4.1. Species Richness. In our study, tree species richness was found to be inversely related to soil $\mathrm{K}, \mathrm{Ca}$, and $\mathrm{P}$ contents,
CEC, and soil fertility index. These results support our hypothesis that there should be some relationships between tree species richness and the different soil fertility factors. As of now, many studies showed some kind of relationships between species richness and nutrient availability [18, 20, 21]. In a tropical forest, Huston $[18,22]$ also found a decrease in tree species richness with increasing CEC, soil fertility index, and concentration levels of $\mathrm{K}, \mathrm{P}$, and $\mathrm{Ca}$ in soil. The author suggested that lower fertility soil generally favoured higher tree species richness $[18,22]$. In lower fertility soil, a naturally strong tree species competitor may lack resources (nutrients) in order to outcompete the other, thereby causing higher tree species richness [23]. Furthermore, many researchers demonstrated a decrease in species richness following soil fertilization which leads to higher soil fertility [21, 23, 24]. The results of these studies all agree with our findings. On the contrary, most studies done in temperate forests and agroecosystems showed positive relationships between tree species richness and soil factors such as soil fertility index and soil Ca, $\mathrm{P}$, and $\mathrm{K}$ contents [5, 25-28]. That difference in pattern between temperate and tropical forests may be caused by the fact that they are completely different ecosystems in different regions of the world.

In our study, tree species richness was not correlated to $\mathrm{Mg}, \mathrm{Fe}, \mathrm{Cu}, \mathrm{Zn}$, and $\mathrm{Mn}$ contents, $\mathrm{C} / \mathrm{N}$ ratio, and total $\mathrm{N}$. These results do not agree with the findings of Nirmal Kumar et al. [9] who found that total $\mathrm{N}$ was highly positively related to tree species richness. This divergence may be generated by a difference in rainfall between the two ecosystems. Precipitation affects soil nutrient availability through its influence on erosion and nutrient cycling [18]. Species richness is also affected by precipitation [29]. Our study was done in a humid tropical forest with high annual precipitation while the study of Nirmal Kumar et al. [9] was achieved in a dry deciduous forest with low annual rainfall. Additionally, Nirmal Kumar et al. [9] and Fu et al. [30] did not find any relationship between tree species richness and the two soil factors: $\mathrm{C} / \mathrm{N}$ ratio and total N, respectively, which agrees with our findings. Tree species richness was more affected by soil fertility than $\mathrm{C} / \mathrm{N}$ ratio in our study.

Species richness of herbs and shrubs was not related to any of the soil variables. Overall, not many studies investigated the relationship between soil chemical factors and species richness of herbs and shrubs. The results in these studies were highly variable. Moore and Keddy [31] suggested that different patterns of species richness may be encountered with different understory species types. Grubb [26] and Goodland [25] discovered a negative relationship between herb species richness and soil fertility. Wright [32] found a positive relationship between soil fertility and species richness of herbs and shrubs. Light availability to herb and shrub communities may affect considerably the relationship because the growth of understory communities is usually highly influenced by light availability and overstory canopy density and volume [33].

4.2. Species Diversity. Shannon-Wiener tree species diversity was only correlated to $\mathrm{C} / \mathrm{N}$ ratio (positive relationship). In tropical forest ecosystems, higher tree diversity tends to occur 


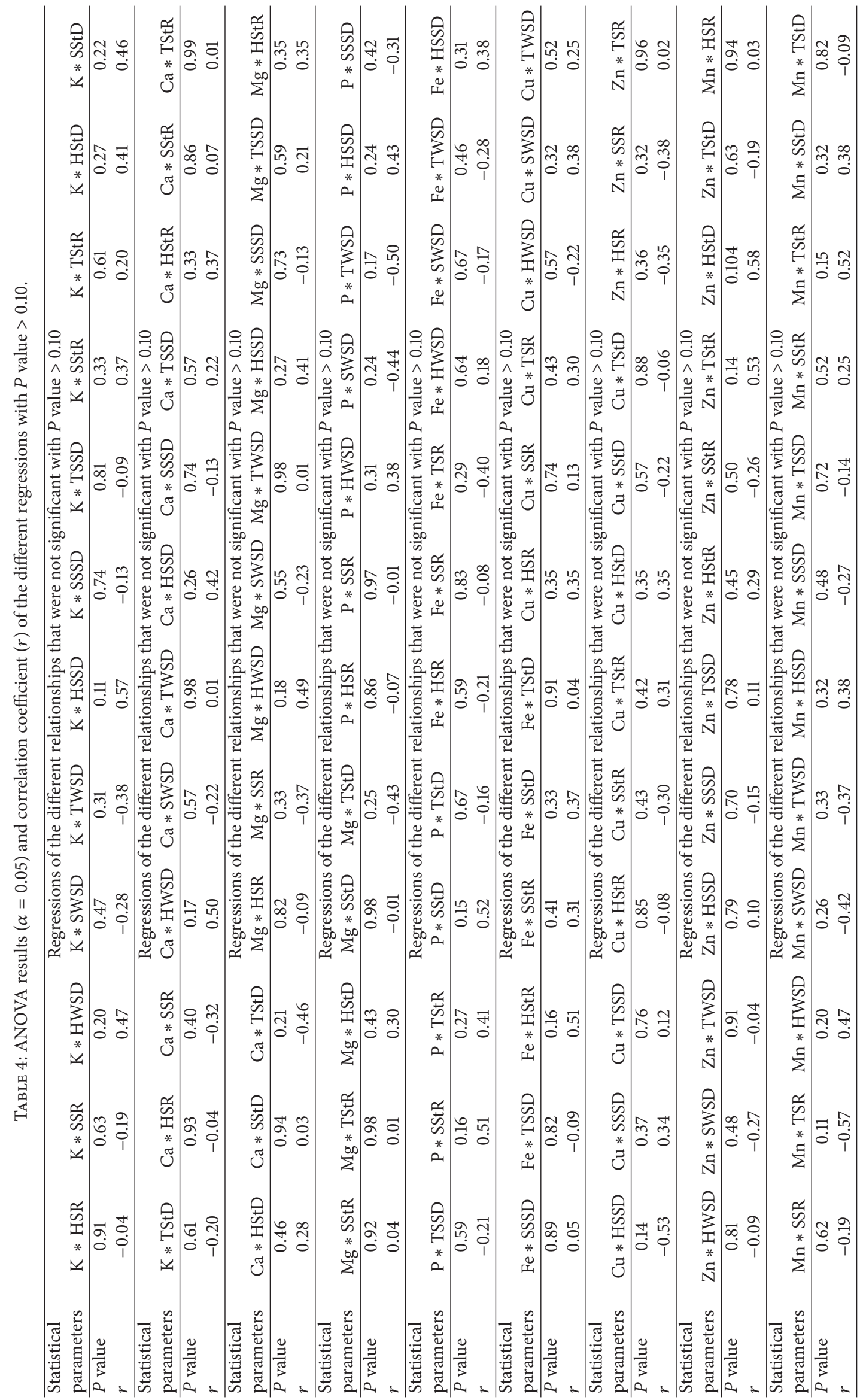




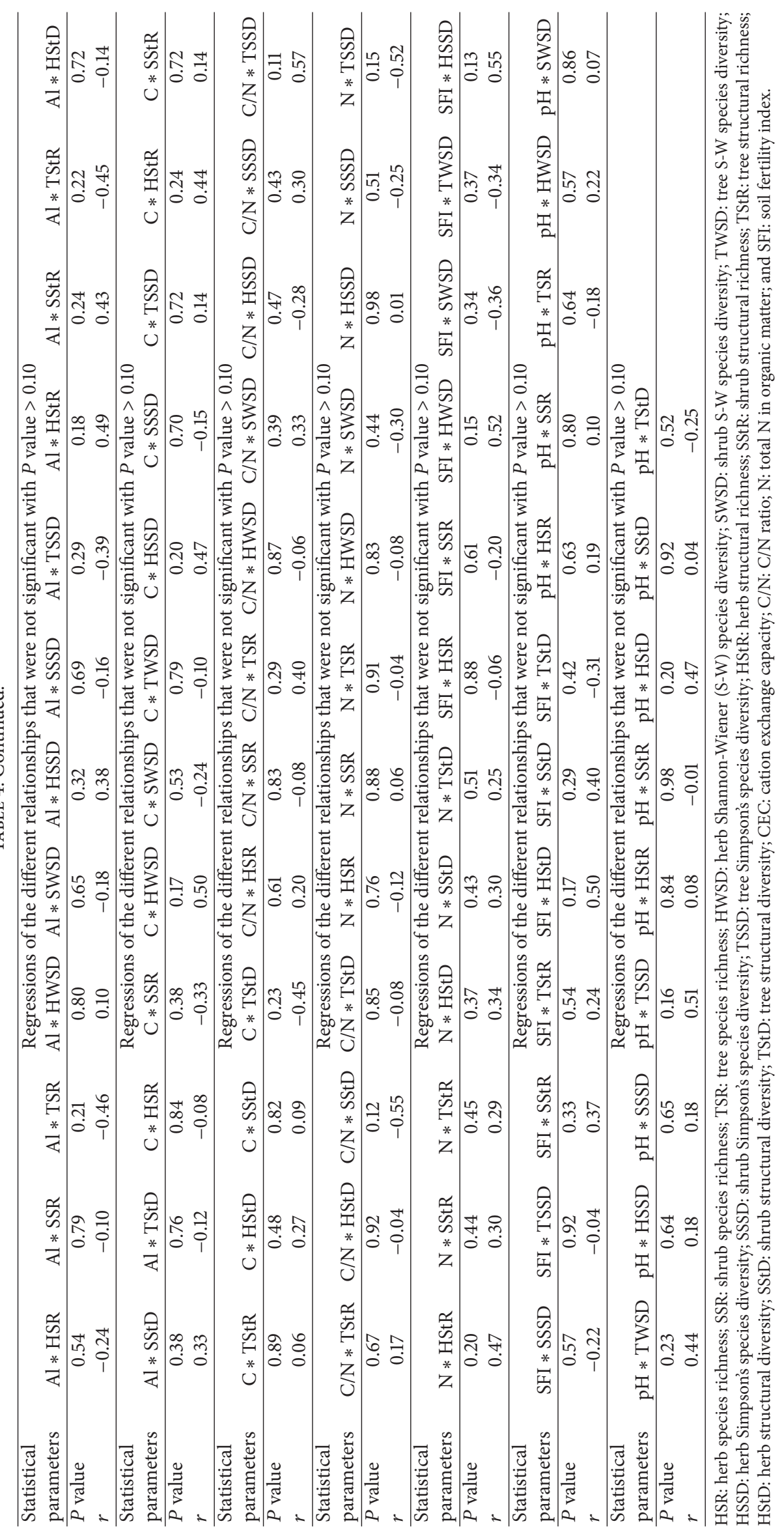


on poor soils with low fertility $[18,34]$. Nitrogen is one of the most important soil nutritional elements and limiting factors for plant growth [35]. Therefore, it makes sense that there is less $\mathrm{N}$ stored in organic matter compared to carbon in those ecosystems with higher species diversity and poor soils.

In our study, Shannon-Wiener tree species diversity was not related to any of the other soil variables $(\mathrm{K}, \mathrm{Ca}, \mathrm{Mg}, \mathrm{P}$, $\mathrm{Fe}, \mathrm{Cu}, \mathrm{Zn}, \mathrm{Mn}, \mathrm{CEC}$, total $\mathrm{N}$, organic $\mathrm{C}$, and soil fertility index). There was no relationship between Shannon-Wiener diversity of herbs and shrubs and any of the soil variables. Also, Simpson's species diversity of herbs, shrubs, and trees was not correlated to any of the soil variables. These findings disagree with many studies done in temperate forests and agroecosystems [36]. Loreau et al. [37] suggested that species diversity is usually related to soil fertility. Also, Grime [20] and Tilman and Pacala [38] demonstrated that soil fertility has a considerable impact on species diversity. Tuomisto et al. [39] found that fern and lycophyte species diversity increased substantially with increasing cation concentration in soil. Tilman et al. [6] established that higher species diversity ecosystems have a greater capacity to utilize nutrients, thereby reducing soil nitrogen leaching loss, which tends to increase soil fertility. Janssens et al. [5] found that species diversity was positively correlated to K content and declined with increasing $\mathrm{P}$ content in soil. Finally, Dybzinski et al. [8] demonstrated that soil fertility and total $\mathrm{N}$ increased with species diversity. These studies probably had different results than us due to the different ecosystems (temperate ecosystems) in which they were conducted compared to our humid tropical forest. Many ecological processes act differently in tropical compared to temperate ecosystems. A good example is soil limiting factor; $\mathrm{N}$ is the soil limiting factor in temperate ecosystems while $\mathrm{P}$ is the limiting factor in tropical forests $[6,18]$. Also, competition, which influences species diversity, tends to play a more important role in temperate forests compared to tropical forests due to niche partitioning by plants that occurs in the tropics [40]. On the other hand, Fu et al. [30] found no relationship between Shannon-Wiener diversity and the three soil factors: total N, $\mathrm{P}$, and $\mathrm{K}$. Janssens et al. [5] reported no relationship between species diversity and the two soil factors: $\mathrm{Ca}$ and $\mathrm{N}$.

Pärtel et al. [41] suggested that dark diversity (unexpressed diversity in a community) is an important diversity index to consider in community ecology studies. It was not measured in our study. The species pool was so high (more than 1,000 species of angiosperms) in the study area and their distribution was largely unknown; thereby, it would have been almost impossible to calculate it accurately.

4.3. Structural Richness and Diversity. The concepts of structural richness and diversity have been widely used in forestry, especially in silviculture management [42]. Forest managers often focus on increasing structural richness and diversity using management practices such as shelterwood, group or individual tree selection, and thinning in order to amplify biodiversity over the landscape [33, 43-48].

In our study, herb structural richness increased significantly with increasing soil fertility index and $\mathrm{P}$ concentration in soil. $\mathrm{P}$ is the most important factor determining soil fertility in tropical ecosystems [7, 18]. Therefore, the herb community may be able to grow taller in soil with higher $\mathrm{P}$ content and soil fertility leading to higher herb structural richness. Zuquim et al. [49] demonstrated that fern community composition was a good indicator of soil cation concentration. Here, we suggest that herb structural richness may be a good indicator of soil fertility. Also, herb structural diversity was positively related to Mn concentration. Manganese does not affect soil fertility much compared to other soil elements such as $\mathrm{P}, \mathrm{K}, \mathrm{Ca}$, and N. Finally, our findings agree with the results obtained by Lindgren and Sullivan [13] where soil fertility did not affect structural diversity of herbs, shrubs, and trees.

4.4. The Effects of Life Zones, Elevation, and Lightness. Plant species richness is known to generally decrease with increasing elevation [50]. Aiba and Kitayama [51] found that tree species diversity in a tropical rainforest of Borneo declined with increasing altitude. In our study, neither life zones nor elevation had an effect on plant biodiversity. One of the main driving forces that explain differences among life zones in Costa Rica is annual rainfall which changes depending on elevation. Precipitation and elevation seem to not have played an important role in controlling plant biodiversity in our mature tropical forest.

There was a divergent relationship between overstory and understory responses to nutrient availability in our study. One may think that this divergent relationship was triggered by a variation in understory light availability generated by different overstory canopy covers. It is well known that partial disturbances leading to secondary forest succession provide resources such as light that attract a wide range of early- to late-successional plant species and allow sustaining high biotic species diversity $[28,52,53]$. Understory light availability declines with increasing canopy cover, which is positively correlated to crown volume index [54]. However, in our study, even if overstory crown index and thereby lightness were highly variable from one sampling plot to the other, there was no significant relationship between overstory and understory crown volume index. As a result, lightness did not account for the different responses of overstory versus understory vegetation to nutrient availability. The divergent relationship may have been caused by another unknown factor.

\section{Conclusion}

Tree species richness of pristine tropical forests decreased considerably as overall soil fertility (CEC, soil fertility index, and $\mathrm{K}, \mathrm{Ca}$, and $\mathrm{P}$ contents) increased. In tropical forests with low soil fertility, strong tree species competitors may lack resources, especially nutrients such as $\mathrm{P}, \mathrm{K}$, and $\mathrm{Ca}$, in order to outcompete the others, thereby causing higher species richness. On the contrary, temperate forests tend to have a positive relationship between tree species richness and soil chemical fertility. This difference may be explained by the fact that tropical and temperate forests are two completely different ecosystems in different climatic regions of the world. Their ecology should be considered separately. In 
the sampled tropical forest, herb structural richness increased significantly with increasing soil fertility index and P content. Higher soil fertility and $\mathrm{P}$ content may enable herb communities to grow taller leading to higher herb structural richness. As a result, herb structural richness may be a good indicator of soil fertility in tropical forests. Little is known about plant structural richness and diversity in tropical forest ecosystems; thus, more studies are warranted.

\section{Conflict of Interests}

The authors declare that there is no conflict of interests regarding the publication of this paper.

\section{Acknowledgments}

The authors would like to thank Ronald Sanchez for allowing them to access the "Reserva Biológica Alberto Manuel Brenes" in Costa Rica. The authors would also like to thank the company "Cafesa" for soil sample analyses and their assistants, Melissa Diaz Morales and Felipe Vega, for taking the time to come in the field to collect all data for this study. Finally, the authors would like to show their appreciation to Professor and Botanist Carlos Morales of the University of Costa Rica who has considerably helped in the identification of plant species.

\section{References}

[1] S. J. Wright, "Plant diversity in tropical forests: a review of mechanisms of species coexistence," Oecologia, vol. 130, no. 1, pp. 1-14, 2002.

[2] T. J. Givnish, "On the causes of gradients in tropical tree diversity," Journal of Ecology, vol. 87, no. 2, pp. 193-210, 1999.

[3] R. B. Waide, M. R. Willig, C. F. Steiner et al., "The relationship between productivity and species richness," Annual Review of Ecology and Systematics, vol. 30, pp. 257-300, 1999.

[4] M. Pärtel, L. Laanisto, and M. Zobel, "Contrasting plant productivity-diversity relationships across latitude: the role of evolutionary history," Ecology, vol. 88, no. 5, pp. 1091-1097, 2007.

[5] F. Janssens, A. Peeters, J. R. B. Tallowin et al., "Relationship between soil chemical factors and grassland diversity," Plant and Soil, vol. 202, no. 1, pp. 69-78, 1998.

[6] D. Tilman, D. Wedin, and J. Knops, "Productivity and sustainability influenced by biodiversity in grassland ecosystems," Nature, vol. 379, no. 6567, pp. 718-720, 1996.

[7] K. D. Holl, "Factors limiting tropical rain forest regeneration in abandoned pasture: seed rain, seed germination, microclimate, and soil," Biotropica, vol. 31, no. 2, pp. 229-242, 1999.

[8] R. Dybzinski, J. E. Fargione, D. R. Zak, D. Fornara, and D. Tilman, "Soil fertility increases with plant species diversity in a long-term biodiversity experiment," Oecologia, vol. 158, no. 1, pp. 85-93, 2008.

[9] J. I. Nirmal Kumar, R. N. Kumar, R. K. Bhoi, and P. R. Sajish, "Tree species diversity and soil nutrient status in three sites of tropical dry deciduous forest of western India," Tropical Ecology, vol. 51, no. 2, pp. 273-279, 2010.

[10] L. R. Holdridge, "Determination of world plant formations from simple climatic data," Science, vol. 105, no. 2727, pp. 367-368, 1947.
[11] A. H. Salazar-Rodríguez, Reserva Biológica Alberto ML. Brenes: veinticinco años de conservación, investigación y docencia, Coordinación de Investigación, UCR, San Ramón, Costa Rica, 2000.

[12] P. F. Stickney, "Data base for post-fire succession, first 6 to 9 years, in Montana larch-fir forests," USDA Forest Service General Technical Report, Department of Agriculture, Forest Service, Intermountain Research Station, Ogden, Utah, USA, 1980.

[13] P. M. F. Lindgren and T. P. Sullivan, "Influence of alternative vegetation management treatments on conifer plantation attributes: abundance, species diversity, and structural diversity," Forest Ecology and Management, vol. 142, no. 1-3, pp. 163-182, 2001.

[14] R. H. Whittaker, "Evolution and measurement of species diversity," Taxon, vol. 21, no. 2-3, pp. 213-251, 1972.

[15] J. Bohl and A. Lanz, The Concept of Structural Diversity, Swiss Federal Institute for Forest, Snow and Landscape Research, Davos, Switzerland, 2002.

[16] S. R. Olsen, C. V. Cole, and F. S. Watanabe, Estimation of Available Phosphorus in Soils by Extraction with Sodium Bicarbonate, United States Department of Agriculture (USDA), Washington, DC, USA, 1954.

[17] C. Lin and N. T. Coleman, "The measurement of exchangeable aluminum in soils and clays," Soil Science Society of America Journal, vol. 24, no. 6, pp. 444-446, 1960.

[18] M. Huston, "Soil nutrients and tree species richness in Costa Rica forests," Journal of Biogeography, vol. 7, no. 2, pp. 147-157, 1980.

[19] A. Kozak, R. A. Kozak, C. L. Staudhammer, and S. B. Watts, Introductory Probability \& Statistics: Applications for Forestry \& the Natural Sciences, Cambridge University Press, Cambridge, UK, 2008.

[20] J. P. Grime, "Competitive exclusion in herbaceous vegetation," Nature, vol. 242, no. 5396, pp. 344-347, 1973.

[21] D. Tilman, Resource Competition and Community Structure, Princeton University Press, Princeton, NJ, USA, 1982.

[22] M. Huston, "Biological diversity, soils, and economics," Science, vol. 262, no. 5140, pp. 1676-1680, 1993.

[23] D. Tilman, "Some thoughts on resource competition and diversity in plant communities," in Mediterranean-Type Ecosystems: The Role of Nutrients, F. J. Kruger, D. T. Mitchell, and J. U. M. Jarvis, Eds., pp. 322-336, Springer, Berlin, Germany, 1983.

[24] G. G. Mittelbach, C. F. Steiner, S. M. Scheiner et al., "What is the observed relationship between species richness and productivity?” Ecology, vol. 82, no. 9, pp. 2381-2396, 2001.

[25] R. Goodland, "A physiognomic analysis of the 'Cerrado' vegetation of central Brasil," Journal of Ecology, vol. 59, no. 2, pp. 411-419, 1971.

[26] P. J. Grubb, "Global trends species-richness in terrestrial vegetation: a view from the northern hemisphere," in Organisation of Communities, Past and Present, J. M. R. Gee and P. S. Giller, Eds., vol. 27, pp. 99-118, Blackwell Scientific Publications, Oxford, UK, 1987.

[27] J. G. Pausas and M. P. Austin, "Patterns of plant species richness in relation to different environments: an appraisal," Journal of Vegetation Science, vol. 12, no. 2, pp. 153-166, 2001.

[28] R. K. Peet and N. L. Christensen, "Changes in species diversity during secondary forest succession on the north carolina piedmont," in Diversity and Pattern in Plant Communities, $\mathrm{H}$. J. During, M. J. A. Werger, and J. H. Willems, Eds., pp. 233-245, SPB Academic Publishing, The Hague, Netherlands, 1988. 
[29] A. H. Gentry, "Changes in plant community diversity and floristic composition on environmental and geographical gradients," Annals for the Missouri Botanical Garden, vol. 75, no. 1, pp. 1-34, 1988.

[30] B. J. Fu, S. L. Liu, K. M. Ma, and Y. G. Zhu, "Relationships between soil characteristics, topography and plant diversity in a heterogeneous deciduous broad-leaved forest near Beijing, China," Plant and Soil, vol. 261, no. 1-2, pp. 47-54, 2004.

[31] D. R. J. Moore and P. A. Keddy, "The relationship between species richness and standing crop in wetlands: the importance of scale," Vegetatio, vol. 79, no. 1-2, pp. 99-106, 1988.

[32] S. J. Wright, "Seasonal drought, soil fertility and the species density of tropical forest plant communities," Trends in Ecology and Evolution, vol. 7, no. 8, pp. 260-263, 1992.

[33] J. F. Franklin, T. A. Spies, R. V. Pelt et al., "Disturbances and structural development of natural forest ecosystems with silvicultural implications, using Douglas-fir forests as an example," Forest Ecology and Management, vol. 155, no. 1-3, pp. 399-423, 2002.

[34] M. Peña-Claros, L. Poorter, A. Alarcón et al., "Soil effects on forest structure and diversity in a moist and a dry tropical forest," Biotropica, vol. 44, no. 3, pp. 276-283, 2012.

[35] N. C. Brady and R. R. Weil, The Nature and Properties of Soils, Prentice Hall, Upper Saddle River, NJ, USA, 1999.

[36] M. A. Altieri, "The ecological role of biodiversity in agroecosystems," Agriculture, Ecosystems and Environment, vol. 74, no. 1-3, pp. 19-31, 1999.

[37] M. Loreau, S. Naeem, P. Inchausti et al., "Ecology: biodiversity and ecosystem functioning: current knowledge and future challenges," Science, vol. 294, no. 5543, pp. 804-808, 2001.

[38] D. Tilman and S. Pacala, Species Diversity in Ecological Communities, University of Chicago Press, Chicago, Ill, USA, 1993.

[39] H. Tuomisto, G. Zuquim, and G. Cárdenas, "Species richness and diversity along edaphic and climatic gradients in Amazonia," Ecography, vol. 37, no. 11, pp. 1034-1046, 2014.

[40] W. Burger, "Why are there so many kinds of flowering plants in Costa Rica," Brenesia, vol. 17, pp. 371-388, 1980.

[41] M. Pärtel, R. Szava-Kovats, and M. Zobel, "Dark diversity: shedding light on absent species," Trends in Ecology and Evolution, vol. 26, no. 3, pp. 124-128, 2011.

[42] K. L. O’Hara, "Silviculture for structural diversity: a new look at multiaged systems," Journal of Forestry, vol. 96, no. 7, pp. 4-10, 1998.

[43] E. Krcmar, G. C. Van Kooten, and I. Vertinsky, "Managing forest and marginal agricultural land for multiple tradeoffs: compromising on economic, carbon and structural diversity objectives," Ecological Modelling, vol. 185, no. 2-4, pp. 451-468, 2005.

[44] F. Montes, M. Sánchez, M. del Río, and I. Cañellas, "Using historic management records to characterize the effects of management on the structural diversity of forests," Forest Ecology and Management, vol. 207, no. 1-2, pp. 279-293, 2005.

[45] H. Pretzsch, "Structural diversity as a result of silvicultural operations," Lesnictvi-UZPI, vol. 44, no. 10, pp. 429-439, 1998.

[46] D. S. Solomon and J. H. Gove, "Effects of uneven-age management intensity on structural diversity in two major forest types in New England," Forest Ecology and Management, vol. 114, no. 2-3, pp. 265-274, 1999.

[47] T. P. Sullivan, D. S. Sullivan, and P. M. F. Lindgren, "Small mammals and stand structure in young pine, seed-tree, and oldgrowth forest, southwest Canada," Ecological Applications, vol. 10, no. 5, pp. 1367-1383, 2000.
[48] T. P. Sullivan, D. S. Sullivan, and P. M. F. Lindgren, "Influence of variable retention harvests on forest ecosystems. I. Diversity of stand structure," Journal of Applied Ecology, vol. 38, no. 6, pp. 1221-1233, 2001.

[49] G. Zuquim, H. Tuomisto, M. M. Jones et al., "Predicting environmental gradients with fern species composition in Brazilian Amazonia," Journal of Vegetation Science, vol. 25, no. 5, pp. 11951207, 2014.

[50] R. Ohlemüller and J. Bastow Wilson, "Vascular plant species richness along latitudinal and altitudinal gradients: a contribution from New Zealand temperate rainforests," Ecology Letters, vol. 3, no. 4, pp. 262-266, 2000.

[51] S.-I. Aiba and K. Kitayama, "Structure, composition and species diversity in an altitude-substrate matrix of rain forest tree communities on Mount Kinabalu, Borneo," Plant Ecology, vol. 140, no. 2, pp. 139-157, 1999.

[52] M. E. Swanson, J. F. Franklin, R. L. Beschta et al., “The forgotten stage of forest succession: early-successional ecosystems on forest sites," Frontiers in Ecology and the Environment, vol. 9, no. 2, pp. 117-125, 2011.

[53] D. A. Wardle, R. D. Bardgett, J. N. Klironomos, H. Setälä, W. H. van der Putten, and D. H. Wall, "Ecological linkages between aboveground and belowground biota," Science, vol. 304, no. 5677, pp. 1629-1633, 2004.

[54] S. N. Martens, D. D. Breshears, and C. W. Meyer, "Spatial distributions of understory light along the grassland/forest continuum: effects of cover, height, and spatial pattern of tree canopies," Ecological Modelling, vol. 126, no. 1, pp. 79-93, 2000. 

